International Journal of Linguistics, Literature and Culture
Available online at https://sloap.org/journals/index.php/ijllc/
Vol. 4, No. 4, July 2018, pages: $112 \sim 126$
ISSN: $2455-8028$
https://sloap.org/journals/index.php/ijllc/article/view/277

\title{
The Abstract of Critical Discourse Analysis of Radicalism Labeling by BNPT to Islamic Site
}

Kholid $^{\text {a }}$

Article history:

Received: 15 March 2018

Revised: 26 June 2018

Approved: 25 July 2018

Published: 31 July 2018

\section{Keywords:}

$B N P T$;

Islamic Site;

Social Media;

Critical Discourse;

Radicalism Labeling;

\begin{abstract}
The development of radicalism issues is begun by a radical group movement and its spread in social media is labeled as a radical element by, The Agency of National Counter Terrorism (BNPT). This research issues radicalism through the language because there is an element of the radical language becoming criteria of radical in social media. Pursuant to factual logical data, views from readers, this research aims at; 1) describing the criteria of the language use labelled radical by BNPT in Islamic pages; 2) investigating the ideology of radicalism views in Islamic pages; 3 ) describing how BNPT views Islamic pages; 4) finding the relevant result toward the discourse analysis learning in universities. The approach used in this study is the Critical Discourse Study approach belonging to descriptive qualitative. This study is based on the theory of Critical Discourse Analysis (CDA) as the main theories and supported by the use of Social Semiotic Theory proposed by Halliday to analyze criteria of radical language. Besides, this study is also based on the theory of ideology by Raymond William and Louis Althusser. To collect the data needed, this study employed observation and documentation techniques. The data gathered were then analyzed by using formal and informal methods. Then, they were categorized, classified, identified, labeled, and the data described. Based on results of the data analysis, it shows the use of the symbol or label criteria radical language, a linguistic and ideological overview of features on the site indicated radical and BNPT's view to that site. By examining from the perspective of macro and microstructure in the text, there are three topics the issue of jihad, demonstrations, takfirin. Besides, the use of microstructure including semantic syntactic, stylistic, rhetorical is the domain in terms of microstructure. In addition, there are micro syntactic and semantic aspects, stylistic, and rhetorical aspects that domain the results.
\end{abstract}

2455-8028 ${ }^{\circledR}$ Copyright 2018. The Author. This is an open-access article under the CC BY-SA license (https://creativecommons.org/licenses/by-sa/4.0/) All rights reserved.

\section{Author correspondence:}

Kholid,

STKIP Weetabula, West North Sumba, Indonesia

Email address: kholilid45@gmail.com

\footnotetext{
${ }^{\text {a }}$ STKIP Weetabula, West North Sumba, Indonesia
} 


\section{Introduction}

By the time goes, the development of radical dissemination issues demanded to be anticipated together, experiences significant fluctuation from individual to individual movements, from one group to another, from one place to another. The implementation is very varied both traditionally and modern such as discussion, question, and answer, convey religious Fatwa (instruction). This may or may not be because it may not necessarily be true between one individual and another and between one group and another group spreading radicalism in the meeting. It is probable that the meeting is aimed at connecting the ropes of silaturrahim (good relationship), giving each other a warning, guiding it based on the true religious teachings and preserving beneficial of ummah (members of the religious community). This can be done either in the family environment, friends or colleagues in the office, in the assembly hall, berugak and places of worship such as in mosques or in mushalla (small mosque).

Different phenomena in this modern era that is in tone with the development, the progress of technological tools that can no longer be contained and controlled may lead some people to strongly depend on taking the principle of practical benefits with the advancement of technology in delivering the da'wah (religious speech) such as conveying the amal ma'ruf nahi mungkar, question and answer about the guidance of religious teachings simply by sending messages via mobile phone and through social media both between one individual with other individuals and between groups with one another group. Indeed, we all know that each individual and group have different views. It can happen and by the time goes it can be observed that more and more views in this day such as the problem of "radical" interesting here in which people who bring religious matters, question and answer problems guidance religion between individuals or groups either directly or indirectly or through the means of social media radical labeled. All of these things, possibilities can happen or not. To anticipate this, people should be more careful in receiving messages either directly or through social media that has elements of conflicting content, SARA issues and related to radicalism. However, researchers view that there is more danger of the Islamic sites indicated to spread radical among them are porn sites and online gambling that is very damaging to the morale of the generations of the nation. It is our joint responsibility, whether the government as the executor of the mandate of the Constitution to crack down or block these sites, lest the Islamic site be acted as a radical dissemination so that there is a shift to the site.

Nowadays, the issue of labeling of religious radicalism that appears both globally and nationally is in fact shifting; for example, globally labeling radicalism is a group of al-Qaida worshipers, the Islamic network often referred to as terrorists. But today, a radically-claimed state called ISIS. While nationally, The Agency of National Counter Terrorism (hereinafter abbreviated as BNPT) as state institution which formerly claimed a radical Islam group, but phenomenon at this time, it is not a group but it is means of technology that is Islamic site until culminating the occurrence of the bending of Islam site with unclear reasons. Revisiting history both in terms of radicalization labeling has occurred a long time ago. Indeed, the labeling of radicalism against a group of Islam has been running with different objects from the old order such as one of the strong Islamic groups such as Darul Islam (DI), Indonesian Islamic Army (TII) led Sekarmadji Mandjan Kustosuewiryo. These movements have a base in the area of West Java, Aceh, and South Sulawesi is aimed to establish an Islamic state of Indonesia (NII) this movement considering the war against the Indonesian government as a form of jihad. This group could have rebelled in West Java in the 1950s but was crushed by the government in 1962 .

Beginning during the New Era, this radical Islamic group is called the right extreme group accused of doing subversive moves by the security forces. The command of jihad and jamaah Islamiah (JI) is a group considered to be the right extreme. Where at that time, it was known as the system of government that always be repressive towards authoritarian community activities that folded against the government. The New Era period is synonymous with religious-based communal conflicts such as Ambon and Poso. Therefore, it triggered some Islamic groups that are considered radical such as Front Pembela Islam (FPI), Laskar Jihad, Majlis Mujahidin Indonesia (MMI) of this group allegedly provide support by sending troops or military. Compared to the Reformation era of Islamic, Shari'a movement appears largely as a result of this phenomenon occurred at that time included crisis cycles, religious revitalization, conflicts that led to the emergence of the formalization of Islamic Shari'ah movement in two conditions namely "structural tension" and cultural tensions. Next, the phenomenon of social marginalizes occurs. This is in the background behind the abolition of the 1945 Jakarta charter. The interesting thing is the development of the emergence of the labeling of radicalism in this democracy where radical labeling is not only outsiders or from the west and not the group but among the government itself. It is proven by the existence of a government policy that blocks Islamic sites that are considered to spread radical elements based on recommendations from an Agent namely

Kholid, -. (2018). The abstract of critical discourse analysis of radicalism labeling by BNPT to Islamic site. International Journal of Linguistics, Literature and Culture, 4(4), 112-126. https://doi.org/10.21744/ijllc.v4n4.277 
BNPT. This movement is motivated by a public report that there are some indications from some Islamic sites that contain content spreading hatred, encouraging jihad, and spreading the issue of SARA (Suarta: 2017, Aryani: 2018).

The Critical Discourse Analysis (CDA) is a form of discourse study that analyzes the practice of power. The concept of power here is a tool used to control something, in the form of discourse that is connected with the community. This means that a discourse can be a form of power practice in the midst of society. In addition, CDA has its own characteristics such as: giving attention to social problems where power relation is discursive, or in discourse, discourse plays role in formation of society and culture, discourses take a role in building ideology, discourse is historical, discourse also mediates the relationship between texts and social societies, interpretive, expository and discourse is a form of social action. Judging from the characteristics of the study of, the researcher argues that it is appropriate to use the CDA approach in researching the phenomena occurring in the action of BNPT to take action to provide radical labeling to social media in this case the Islamic site as it is clear that the discourse developed by BNPT raises a social action with the language used that the ideology built by BNPT assumes Islamic sites disseminate radical ideas that disbelieve people, encourage Jihad and spread the issue of SARA.

\section{Research Methods}

Methods of data collection used in this study were observation and documentation. There were two stages conducted in the observation including checking or observing some of the Islamic sites indicated by radicalism and documenting was conducted by the to strengthen and complete the more accurate data by downloading all the Islamic sites indicated to spread the content of hatred, Jihad and spreading Ethnicity, Religion and Race issues. Researchers found 19 sites that are considered to spread the radical understanding labelled by BNPT; yet, only 3 sites were taken to be used as samples for the data research. Since then, researcher began to be interested in collecting and identifying some books, articles, journals, and research related to the discourse of radicalism, especially those labeled by BNPT. All the sources of the written references gotten by a researcher in different ways: by accessing data from websites and some research journals. Secondly, researchers began mapping documents on radicalism which further compiled them in the form of descriptive and comparative. Finally, this research performs analysis from research result to get description about the strengthening of radicalism discourse in Islamic site (Setiawan: 2015, 2016).

Data analysis method was conducted through mixed-method composed of descriptive qualitative and quantitative descriptive qualitative method was used to analyze clauses developed from microstructure, superstructure and microstructure presented in the table. Meanwhile, descriptive quantitative was conducted to describe the criteria of radical language, ideology and perspective of BNPT on the text posted by Islamic sites indicated as sites with radical content.

The results of data analysis are presented using two methods: formal and informal methods. Formal methods are used to present the results of data analysis (clauses) using tables or schemes. Meanwhile, informal methods are performed by presenting the data described in sentence or paragraph form.

\section{Theoretical Framework}

In this research, there are several concepts needing to be referred to and described as a basis of this study namely of radicalism, terrorism and critical discourse analysis. Radicalism is a quality or statement or principle or political doctrine or deep-rooted social change (Webster's dictionary, as quoted by Zen, 2012: 1). Radicalism is a notion demanding a change towards the government in a society in which every action uses violence and like to impose the will. Radicalism has a history generated with fanaticism, intolerance and exclusiveness in the first Islam revealed by the Khawarij since the first century of Hijriyah (Santosa, 2012). Terrorist crime actors are called terrorists. Although the term is clear, its meaning becomes blurred when it should be called who they are and what actions can be categorized as terrorism. In the literature, terrorism is a person, or group of people without the right and authoritative authority to commit frightening, threatening, endangering safety, and even killing another person. Thus, "terrorist" in this sense is the person or group of persons acting outside the official institution. About the perpetrators of terrorism, Tb. Ronny Rahman Nitibaskara argues that the perpetrators of this crime can be distinguished between individuals and organizations. Qualitatively, the rage of terror spread by individual actors is no less crushing than the actors of organized groups. Terrorist terms by counter-terrorism experts are said to refer to perpetrators who do not belong to the armed forces known or not to follow the rules of the armed forces. The action of terrorism also means that terrorist attacks are not humane and have no justification, and because of that situation the perpetrators ("terrorists") deserve a cruel reprisal. Due to the negative meanings contained by the terms "terrorist" and "terrorism," terrorists 
generally refer to themselves as separatists, freedom fighters, crusaders, militants, Mujahideen, and others. As for the true meaning of Jihad, Mujahidin is far from acts of terrorism that attacks civilians when it is not involved in war. Terrorism itself often appears in the name of religion. Besides by individual perpetrators, terrorism can be done by the state or known as state terrorism. State terrorism like terrorism in general is controversial, and for that reason there is no commonly accepted definition. One focus of critical discourse analysis is the power of law. Van Dijk (1993: 254) mentions that on power, it can be seen that power contains controls that can limit the movement of a person or a group, even more so when such controls can influence the thinking of the crowd to drive their actions. When it happens, it can be said that there is a practice of power in it. In discourse analysis there are three important things that affect production and discourse analysis namely: ideology, knowledge, and discourse. Ideology affects discourse production. There is no discourse that is completely neutral or sterile from the speaker's or creator's ideology. Teun van Dijk (1997) analyzes critical discourse in order to reveal how power, dominance, and inequality are practiced, reproduced or opposed by written texts as well as conversations in social and political contexts. Thus, the CDA takes a nonconformist position or opposes the flow of dominance in a large framework against social injustice (compare Setiawan, 2015); (Setiawan, 2016).

Critical Discourse Analysis used in this research is a model of critical discourse analysis proposed by van Dijk. Van Dijk defines Critical Discourse Analysis (CDA) as follow;

Critical discourse analysis (CDA) is a type of discourse analytical research that primarily studies the way social power abuse, dominance, and inequality are enacted, reproduced, and resisted by text and talk in the social and political context. (2001: 352).

By the aforementioned definition, van Dijk sees critical discourse analysis as a form of discourse analysis that specifically focuses on abuse of power, dominance, inequality, alignments contained in a text. Critical discourse analysis not only deals with the linguistic elements but also with how a text is formed, formed, produced and understood by the community. The text can be both oral and written. One focus of critical discourse analysis is the practice of power.

Power practice in critical discourse analysis can also be seen in the mass media. Van Dijk (1995: 10) mentions that "Media power is generally symbolic and persuasive, in the sense that the media primarily have the potential to control the minds of readers or viewers, but not their actions." The media has the potential to control and influence the minds of its readers so that the media can be one of the tools to exercise the power of attorney.

The van Dijk analysis here links textual analysis solely focusing on the text to a comprehensive analysis of how the text is produced, both in relation to individual journalists and from society. The van Dijk model can be described as follows: Context, Social cognition, and text. Teun van Dijk sees a text consisting of several structures / levels in which each part supports each other. It divides it into three levels, namely the first microstructure. This is a global / general meaning of a text that can be observed by looking at the topics/themes put forward in a story. The second superstructure is a discourse structure that deals with the framework of a text, how parts of the text are composed into the story as a whole. The third Micro Structure is the meaning of discourse that can be observed from a small part of a text word, sentence, proposition, clause, paraphrase, and picture. Discourse analysis not only limits attention to the structure of texts but also how the texts produced. Van Dijk offers an analysis called social cognition.

Other supporting theories used in this research is the ideological theory proposed by Raymond William and Louis Althusser. Meanwhile, there is a discourse on how a news is interpreted? Meanings are produced through the active and dynamic process both from the process of manufacture and audience readers. Readers and news texts are equally contributing to meaning-producing, and in the said relationship, a reader's or audience is a part of its relationship to the larger system of values where they live in society. It is at this point that ideology works (Fiske, 1990: 164). One of the key points in Althusser's theory of ideology is his concept of subject and ideology. In essence, ideology in Althusser's view always requires a subject and the subject needs an ideology. Ideology is the result of the formulation of certain individuals. Its applicability demands not only the group in question. However, besides needing a subject, ideology also creates a subject. This effort is called interpellation (Cahyadi in Driyarkara Editorial Team, 1993: 5556). Meanwhile, the media also contains interpellation. We adopt certain social positions or social relationships in which one's position is determined. As Tolson puts it, text / news media always greet someone and puts someone in when reading or watching a story (Tolson, 1996: 53). Why is it perceived so? Because media news is basically not intended for itself, the media message is basically intended to communicate with audiences. The news of Jihad on Islamic sites, not only aimed at the group alone but this news also want to greet audiences of readers whose goal is to convey the message of ma'ruf nahi mungkar.

Kholid, -. (2018). The abstract of critical discourse analysis of radicalism labeling by BNPT to Islamic site. International Journal of Linguistics, Literature and Culture, 4(4), 112-126. https://doi.org/10.21744/ijllc.v4n4.277 
Althusser's theory of ideology emphasizes the power of the dominant group in controlling other groups. The question is, how the way or the spread of this ideology is done? At this point, the concept of hegemony popularized by the prominent Italian political philosopher Antonio Gramsci deserves to be put forward. Gramsci constructs a theory that emphasizes how acceptance of a group dominated by the presence of a dominant group takes place in a peaceful process, without violence. Mass media can be a means by which one group reinforces its position and demeans the other. This is not to say that media is a manifestation of evil forces that deliberately demean the lower classes

This theory of social semiotics is also a theory supporting this research impressing on a sign made by humans in the form of language or language as a sign of this is a social semiotic put forward by Halliday (1978). In social semiotics, which expresses meaning in a text, there are three elements that become the center of attention, such as the flied of discourse, which shows the discourse of the perpetrator (social media) about something that is happening in the field. The discourse of the tenor of discourse shows people who are included in the text (news); the people, their positions, and roles. In other words, who is quoted and how the source is portrayed. The mode of discourse shows the part played by the language: how the communicator (social media) uses the language style to describe the field (situation) and tenor (people quoted).

\section{Results and Analysis}

\subsection{Analysis of Criteria of Radical Language in Text of Islamic Site}

The development of radical issues that cannot be separated from the political shift cannot be denied in the present time. It starts with the labeling of radicalism and social media movements targeted by the labeling of radicalism. It is all a challenge for people to answer. Related to the discourse of labeling of radicalism was reconstructed by BNPT, a certain criteria, becoming the basis for labeling Islamic media allegedly spreading radical issues. All of these things are symbols or marks given by BNPT to mark or label the person or object indicated spreading the issues of radicalism, these are all forms of social semiotics. BNPT, as an institution gives the symbol to some Islamic media with label spread of radicalism and Islamic media as the object of labeling it.

In this study, the issue of discourse labeling radicalism in social media is interesting to discuss. This radicalism labeling discourse was initiated by BNPT's statement by recommending Minister of Communication and Information of Republic of Indonesia and then following up by ordering the Internet Service Provider (ISP) to do the social media which is part of the Islamic site indicated to spread radical issues. This shows the application of social semiotics using social semiotics. In the view of Halliday (1978: 110) in social semiotics, expressing the meaning in a text, there are three elements that become the center of attention namely the field of discourse (Field), discourse participants (Tenor), and setting of discourse (Mode).

\section{a) Medan Wacana (Field)}

This discourse field discusses the discourse of labeling radicalism on social media namely; there is an Islamic site indicated to spread radicalism, so the occurrence of blocking on the grounds that there is a radical language criterion which is the basis that the site contains content invites jihad, spreading hatred, Takfirin, contains elements of Ethnicity, Religion, and Race (SARA). This is recommended by BNPT letter 149 / K. BNPT / 3/2015. Concerning the findings on aspects of discourse in Halliday's social semiotics, the discourse presented concerns the labeling of radicalism of Islamic media indicated to have radical language criteria contained in the form of article meaning that there is a radical element of the language contained in the article indicated the spread of radicalism by using an invitation language jihad, but labeling the discourse of the spread of a radical language like this must have the meaning behind the social action that is done by BNPT, labeling motive is just a label just radical or to know anywhere the pros and cons against the owner of the site by identifying and reconstructing the discourse labeling the radicalism. If we refer to the linguistic feature that the word jihad is derived from the Arabic of the origin it says that jaahada-yujahidu-jihadan which means exerting all effort and trying hard to face the difficulties of fighting the enemy and resisting its aggression. This is when we look at the form of language, but different interpretations that the word jihad has a broad meaning. Jihad has a meaningful interpretation that is very influential with one's ideology. In the article, to discuss the problem of jihad with his ideology is to prevent the words saying that Amal ma'ruf nahi mungkar with the aim of conveying the religious thing. It does not mean jihad invites to fight in accordance with the interpretation and labeling of radicalism by BNPT jihad issue. Articles containing jihad contained on the site Arrahmah.com and so forth. Therefore, the researchers argue that 
in this study there is two interesting discourse first built by BNPT with the discourse of labeling the spread of radicalism. Both discourses on the spread of radicalism on Islamic sites indicated radical. In the end, the social action done by BNPT does not have the legal power besides giving recommendation to Ministry of Communication and Information to make the site of retreat indicated the spread of radicalism is a violation of the Constitution because the site has a legal umbrella or incorporated law, human rights violations in freedom of expression because our country is based on democracy. Similarly, loading an article with an idea that is a social action carried out by our brothers who persistently convey religion and keep in mind to be careful in conveying language that is easily interpreted by many parties, this is basically if there is no social reaction to what is poured in the article then there will be no problem, indeed the prevention of radicalism is our common duty, we must prevent by way of consolidation to the society who have interests and interconnections within the country that we are proud of.

b) Mode of Discourse

The relevance of the problem of the discourse means that this form of a linguistic feature in conveying the message in the text found many active, passive sentences such as war, demonstrating, jihad, contain radicalism. The metaphor form takfirin, kuffar, tub stamp, jihad as the antidote.

\section{c) Tenor of Discourse}

In this research, as for the first discourse of Saud Usman Nasution, as the head of BNPT in 2015, the Director General of Communications and Information Technology and The Minister of Communication and Information, Rudiantara, all the discourse of the discourse in this case states that there are indications of Islamic sites that spread radicalism by taking social action into counter-productive acts by labeling such sites. Yet the strange reason for the blocking developed is because the Islamic sites mentioned above are considered to have vilified Jokowi [Republika, 31/5/2015]. The reason for "vilifying Jokowi" is, of course, ridiculous and the definition is not clear. This could be biased with the media that is really critical of conveying the truth, without any element of humiliation / contempt. It could be that this reason appears because The Ministry of Communication and Information and BNPT aware that blocking Islamic sites do not have a legal umbrella. It is different with blocking pornography site in which there is a legal umbrella that is Law No. 11 of 2008 on ITE and Law No. 44 of 2008 on Pornography. Then the reason diverted to the issue of vilifying Jokowi, in order to get snarled insulting article in the Law of ITE. Amore bizarre, in a meeting of the editor of Islamic media with The Minister of Communication and Information presented by Irfan Idris, director of BNPT Deradicalization, he reveals the reason the Islamic site was blocked because it uses domain dot com (.com) which is a domain for the United States. According to him, which is allowed in Indonesia is a site with dot co dot id domain (.co.id). [Fimadani, 31/3/2015]. The second party that became the result of the discourse was the owner of the site that became the target of the indication of the bombing contained radical languages that cause social reactions. The third party that became the result of the central MUI discourse which states that have admitted though there are sites that are provocative, the majority of sites- the Islamic site is good. In my observations, only 3 are provocative, while the rest are good. The majority of the alleged sites do not support ISIS. For example, the blocked gemaislam.com site belonging to the Al Irsyad Islamic mass organization has been a partner of BNPT in the socialization of fighting terrorism and has held seminars on the dangers of ISIS and terrorism in August 2014. [Republika, 31/3/2015].

\subsection{Ideological Analysis of Radicalism In Islamic Site Text}

This analysis is in line with the formulation of the problem of how the ideology of radicalism in the text of Islamic sites. The data found in the text of Islamic sites such as macrostructure with the theme "al-Jihad is medicine". This is a linguistic feature as an ideology in delivering religious matters. 
a) Data Analysis One

Table 1

Macro discourse structure

\begin{tabular}{ccc}
\hline Discourse Structure & Observed thing & Element \\
\hline Micro-Structure & Thematic & Topic \\
& Al-Jihad is medicine & \\
\hline
\end{tabular}

It is questionable that why this theme is shown, judging from the view that the word al-jihad here means something done to influence a situation both morally and materially because it is the background of the theme is a form of solidarity towards the brother the faithful brothers in Palestine, Syria, Iraq and the oppressed Lebanese, are doomed by irresponsible people to display such themes that have very wide meaning. The word medicine is something that can give a change of state both born and inner suffered by people. When it is viewed from the theme al-jihad as medicine, according to the impression contained in the theme is that the situation at that time our brother is being oppressed (dizhalimi) so that his thoughts to treat our brothers one street with jihad appear. As for the image of a similar impression that fellow believer is like not much difference from one limb. When one limb gets sick then the pain will be felt in the other members. This is the basis for the emergence of the theme. Judging from the form of the word Jihad which has a broad meaning not defining jihad by going to take up the weapon of the region, but jihad here is meant by oral or by way of preaching and praying our brother who is eagerly given the end of fortitude and strength.

Based on the above explanation that the theme of "al-jihad is medicine" is displayed on the text of the Islamic site whose impression is seen as a connotative meaning so that it is labeled radicalism by BNPT which is the question whether the basic theme is said to be radicalism? What is the effect of the theme on the social situation, whether if the theme raises, it will emerge social reaction where in fact there is no safe? When it is viewed from the structure of the scheme / path where the opening of the text exists, researchers find the plot like a quote in the table below.

Table 2

Microstructure element

\begin{tabular}{|c|c|c|}
\hline $\begin{array}{l}\text { Discourse } \\
\text { Structure }\end{array}$ & Things observed & Element \\
\hline Superstructure & Schematic & Scheme or plot \\
\hline & $\begin{array}{l}\text { "Sesungguhnya setiap amalan (ibadah) di dalam Islam } \\
\text { mempunyai keutamaan dan keistimewaan. Rasulullah } \\
\text { sholallahu alaihi wasallaam telah mengabarkan bahwa jihad } \\
\text { adalah seutama-utama dan setinggi-tinggi ibadah dan medan } \\
\text { jihad (medan ribath) merupakan semulia-mulia tempat di } \\
\text { permukaan bumi. } \\
\text { "Indeed, every practice (worship) in Islam has virtue and } \\
\text { privilege. Rasulullah sholallahu 'alaihi wasallaam has } \\
\text { preached that jihad is as foremost and ultimate in worship and } \\
\text { the field of jihad (medan ribath) is a glorious place on the } \\
\text { surface of the earth. }\end{array}$ & Opening \\
\hline
\end{tabular}

It is seen that the plot of the text is the beginning of the displayed text that reveals the virtues and privileges of jihad and jihad. This is conveyed as a plot of opening as the following quotation "the most important and highperforming work is jihad while the field or place of jihad is noblest" on the surface of this earth. Why did the opening line appear like that? The purpose of the author is to give good news to those who do charitable deeds to be motivated to do the things recommended according to the Quran and Al-Hadith. This is the basis for the rise of such a path. In accordance with the background of the text in terms of what is labeled radical? if according to this researcher all is delivery of religion case which guide and this matter are viewed with a different viewpoint. 
Table 3

Rhetorical micro structure element

\begin{tabular}{clc}
\hline Discourse Structure & \multicolumn{1}{c}{ Things observed } & \multicolumn{1}{c}{ Element } \\
\hline Micro-Structure & \multicolumn{1}{c}{ Rhetorical Part } & Graphic dan metaphor \\
\hline & "Sesungguhnya setiap amalan (ibadah) di dalam Islam (ibadah), Solallahu \\
& $\begin{array}{l}\text { mempunyai keutamaan dan keistimewaan. Rasulullah 'alaihi wasallaam, } \\
\text { olallahu alaihi wasallaam telah mengabarkan bahwa (medan ribath) } \\
\text { jihad adalah seutama-utama dan setinggi-tinggi ibadah dan }\end{array}$ \\
& medan jihad (medan ribath) merupakan semulia-mulia \\
& tempat di permukaan bumi. \\
& "Indeed every practice (worship) in Islam has virtue and \\
& privilege. Rasulullah olallahu 'alaihi wasallaam has \\
& reported that jihad is as foremost and foremost the worship \\
& and field of jihad (medan ribath) is a glorious place on the \\
& surface of the earth.
\end{tabular}

In addition, the table above represents a rhetorical micro-component of graphics and metaphors such as word (worship) and the word ribath displayed in the text with oblique letters and parentheses that have the meanings of all the deeds of the highest values of worship that is jihad; it is similar to the word ribth that is a glorious place, a field or a place of jihad. Therefore, these all things is the protrusion of the virtue of worship and ribath. The word "sholallahu 'alaihi wasallaam" is a display of words that have meaning so that we do not forget to say shaskat to Prophet Muhammad "sholallahu' alaihi wasallaam" because with this utterance we can get intercession on the Day of Resurrection so it is also skewed. The word and is the micro discourse structure of the syntactic part, in which the word form and show the connecting link between words or sentences with each other.

Among the second plot of the text is the content of the text, the virtue of jihad here is jihad as the antidote.

Table 4

Superstructure element

\begin{tabular}{ccc}
\hline Discourse Structure & Things observed & Element \\
\hline Super Structure & Schematic & Content \\
& "al-Jihad fie sabilillah adalah obat penawar, penyembuh luka & Cont \\
& dan bara hati umat Islam akibat tekanan, sungutan, siksaan, \\
& pembunuhan, pembantaian, dan kedzoliman kaum kuffar \\
& Yahudi, Nasrani, Zhalimin, Munafiqin terhadap mereka", \\
& "Al-Jihad fie sabilillah is an antidote, wound healer and \\
& embers of the Muslims due to the pressure, murder, torture, \\
& killing, slaughter and persecution of Jewish kuffar, Christian, \\
& Zhalimin, Munafiqin against them" \\
\hline
\end{tabular}

In the above excerpt, the findings are the content in the text which means to give an insight into how the virtues and features of jihad work are, among others, as an antidote, due to pressure, torture, homicide done by kuffar. The meaning of such a text clause is to express an impression of our sympathy and impatience by caring for each other and helping our oppressed brother by the zhalim ruler so that we are always wary of their actions and as a motivation we should not be weak in facing the enemy where we should continue to be zealous and fight against kezhaliaman when our brothers of faith are oppressed, persecuted both with moral and material help. This all means of the virtue of jihad in the text. In the groove, there is also part of the structure of other discourse.

Kholid, -. (2018). The abstract of critical discourse analysis of radicalism labeling by BNPT to Islamic site. International Journal of Linguistics, Literature and Culture, 4(4), 112-126. https://doi.org/10.21744/ijllc.v4n4.277 
Table 5

Bagian Struktur Wacana Super Struktur

\begin{tabular}{|c|c|c|}
\hline Discourse Structure & Things observed & Element \\
\hline Super Structure & Schematic & Scheme or plot \\
\hline \multirow{4}{*}{ Micro-Structure } & $\begin{array}{l}\text { "al-Jihad fie sabilillah adalah obat penawar, penyembuh luka } \\
\text { dan bara hati umat Islam akibat tekanan, sungutan, siksaan, } \\
\text { pembunuhan, pembantaian, dan kedzoliman kaum, kuffar } \\
\text { Yahudi, Nasrani, Zhalimin, Munafiqin terhadap mereka" } \\
\text { "Al-Jihad fie sabilillah is an antidote, wound healer and embers } \\
\text { of the Muslims due to the pressure, murder, torture, killing, } \\
\text { slaughter and persecution of Jewish kuffar, Christian, Zhalimin, } \\
\text { Munafiqin against them" }\end{array}$ & Content \\
\hline & $\begin{array}{l}\text { Syntax } \\
\text { Mereka (thev) }\end{array}$ & Pronoun \\
\hline & $\begin{array}{l}\text { Stilistik (Style) } \\
\text { al-jihad fie sabilillah, kaum kuffar }\end{array}$ & Lexicon \\
\hline & $\begin{array}{l}\text { Obat penawar (antidote), bara hati (embers of the heart) } \\
\text { (wounded heart) }\end{array}$ & Metaphor \\
\hline
\end{tabular}

In the above table that includes the superstructure of the schematic part of the Fill flow, there is a section of a microstructure such as in terms of their syntax, they are the pronouns of Muslims who have been dizhalimi by the kuffaar. There are also lexicons or options such as the word al-jihad fie sabilillah, the kuffar there is one lexicon linkage with the other lexicon so that the lexicon is displayed. The word al-jihad fie sabilillah which has the meaning of fighting both with the morals and material path of Allah SWT and is the emphasis that categorized jihad is not fighting but people who study science is called fie sabilillah. The word kuffar is a form of class expression addressed to all non-Muslims both Jews and Christians. The word obat penawar (antidote) and bara hati (embers of the heart) include the rhetorical microstructure of the rhetorical element which is a metaphorical element and both words serve as a form of expression of the language used in the text which shows the sense of impatience and maybe all this is related to the heart of deep feelings in conveying messages that have meaning likened obat penawar (antidote), jihad can give a sense of joy. By jihad in the context of providing moral and material support such as by praying to be given the strength and strength of faith by Allah SWT in facing the enemy. The word of bara hati (embers of the heart) that has the meaning of a hurt heart or a wounded heart with the inhumane acts by the unbelievers and their allies.

Table 6

Super and Micro Structure of Discourse

\begin{tabular}{clc}
\hline Superstructure & \multicolumn{1}{c}{ Semantic } & Meaning \\
\hline & "Tidak ada suatu tempat yang paling indah dan sesuai untuk & Content \\
& menyelesaikan urusan perselisihan antara Muslimin dan kafirin & \\
& lebih baik dari pada medan jihad fie sabilillah" & \\
& "There is no place that is most beautiful and appropriate to settle the & \\
& matter of disputes between Muslims and kafirin better than the field & \\
& of jihad fie sabilillah" & \\
Microstructure & Pyntax & Pronoun \\
& $\begin{array}{l}\text { Mereka (They) } \\
\text { Stylistics } \\
\text { al-jihad fie sabilillah, obat penawar (antidote), kaum kuffar, bara } \\
\text { hati (embers of the heart) }\end{array}$ & \\
\hline
\end{tabular}

Based on the above explanation, the semantic part of the content that has the meaning of the message conveyed in the clause above illustrates the ideological form constructed in the text. Indeed, if we consider the sentence of the text "tidak suatu yang paling indah dan sesuai untuk menyelesaikan masalah dengan orang kafir 
adalah dengan jihad fie sabilillah" (not a most beautiful and appropriate to solve problems with unbelievers is with jihad fie sabilillah). If we look from the side of the text itself, this is something very extreme, but there is a hidden meaning outside text i.e. the social context such as the word jihad meaning not only arms but will bring the case of religion or spread the syiar of Islam with $d a^{\prime}$ wah so in this text, its explicitly meant that jihad or by way of preaching against infidels sampai (until) he embraced Islam. The word Jihad fie sabilillah has the meaning that in acting everything must be with the intention of Allah SWT, both matters of jihad and charity sholeh will be counted in vain for intention besides Allah SWT even against the infidels, but intention wants to be praised by many people that he has strong power then this is a matter of vain that has not been said jihad fie sabilillah or da'wah solely because Allah SWT and Islam teaches no violence and coercion in embracing religion so that the meaning contained in the text.

The word untuk (for) shows that there is a relationship between one clause and another clause. The word mereka (they) is a pronoun meaning that there is the involvement of the oppressed Muslim people whose meaning is no difference and the separator between the author and the reader. The word kuffar, the lexicon form or word choice that has a meaning that is expressed in the mention of all groups of non-Muslims both Christians and Jews who are appointed as perpetrators in oppression and tyranny. The word obat (antidote), bara hati (embers of the heart) is a form of lexicon that has a meaning in the text is there is a behavior of injustice against the Muslims so that this lexicon is raised as a form of expression, sympathy, and impatience to Muslims who are oppressed (dizhalimi). The following data is quoted below "Mereka tidak boleh merasa segan, tidak boleh merasa takut berperang dengan kaum kuffar dan musyrik" (They should not feel reluctant, should not be afraid of fighting with the kuffar and polytheist)

Table 7

Super and microstructure of discourse

\begin{tabular}{clc}
\hline Discourse Structure & \multicolumn{1}{c}{ Things observed } & Element \\
\hline Super Structure & \multicolumn{1}{c}{ Semantics } & Meaning \\
& "Mereka tidak boleh merasa segan, tidak boleh merasa takut & Content \\
& berperang dengan kaum kuffar dan musyrik" (They should not feel & \\
& reluctant, should not be afraid of fighting with the kuffar and & \\
& idolaters) & Pronoun \\
Micro-Structure & Sintaksis & \\
& Mereka (They) & Clause \\
& Berperang (fighting), merasa (feeling afraid) & Lexicon \\
& Stylistic & \\
& Merasa segan (reluctant), merasa takut (afraid), musyrik (polytheist) &
\end{tabular}

The meaning of the above clause where the word mereka (they) is a pronoun addressed to the Muslims who should not be afraid of a war that shows involvement and does not become a separator between readers and writers. The word berperang (fight), merasa (feel) are the form of active sentence which are displayed as a response of a believer because they are associated with the state of the situation in which if we are afraid, reluctant then it will continue to create violence, oppression, and so forth against the believers. For Mukmin (believers) losing or winning the war is all the provisions of Allah SWT. The most important is that we try so that the word berperang (fight) and merasa (feel) were displayed as a form of response by way of trying. The word polytheism here shows the non-tolerant pagans to the Muslims who should be fought.

From the data in the text above, it is found syntactic microstructures that can be seen in the data citation below. "Ia juga mengingatkan bah abovwa kaum kuffar dan musyriklah yang memulai pencerobohan" (He also warned that the kuffar and the polytheists who initiated the recklessness).

Kholid, -. (2018). The abstract of critical discourse analysis of radicalism labeling by BNPT to Islamic site. International Journal of Linguistics, Literature and Culture, 4(4), 112-126. https://doi.org/10.21744/ijllc.v4n4.277 
Table 8

Microstructure of discourse

\begin{tabular}{ccc}
\hline Discourse Structure & \multicolumn{1}{c}{ Things observed } & \multicolumn{1}{c}{ Element } \\
\hline Micro-Structure & \multicolumn{1}{c}{ Stylistic } \\
& $\begin{array}{l}\text { Kuffar and musyrik (polytheist) } \\
\text { Syntax } \\
\text { Mengingatkan (warning), memulai } \\
\text { (initiating) }\end{array}$ & Lexicon \\
\end{tabular}

Based on the data presented above, there is a section of the microstructure that is a stylistic element which has a lexicon. Lexicon contained in that part is the word of kuffar and musyrik (idolater). The word kuffar have the meaning of the part of the people who are not grateful for the blessings of Allah SWT in general both nonMuslims and Muslims. The lexicon of the word musyrik (polytheist) has the meaning of a group of people who are specifically addressed ie the Gentiles both Jews, Christians etc. This shows the difference between the reader and the author. The word reminds and begins as a form of an active sentence whose purpose gives a view and any reaction made by a person to explain something of the incident.

The data are further cited below; "mereka hanya memainkan peranan melaksanakan rencana dan kehendak (qudarat) Allah untuk mengadzab dan menghinakan musuh-musuh Allah dan sekaligus musuh-musuh mereka juga" (They only play the role of carrying out God's plan and will (qudarat) to admonish and humiliate the enemies of Allah and their enemies as well)

Tabel 9

The element of the rhetorical microstructure of discourse

\begin{tabular}{cll}
\hline Discourse Structure & \multicolumn{1}{c}{ Things observed } & Element \\
\hline Microstructure & Rhetoric & Graphic and Metaphor \\
& Quadrat (Quadrate) & \\
& Syntax & Clause \\
& Memainkan (playing), melaksanakan (carrying & Kata ganti, penghubung \\
& out), menghinakan (humiliate), mengadzab & \\
& (admonish), dan mereka (they) & \\
\hline
\end{tabular}

The data found from the above clause is a form of the graphic as a form of appearance that can be seen the brackets of the word qudrat (quadrate) and oblique letters that have a special emphasis on everything that regulates and determine the earth is Allah SWT. This is characteristic of the graphic form so that it is skewed and bracketed. It is an element of the rhetorical microstructure. The word quadrat (quadrate) can also be the metaphor meaning that the will or the provision where the relation of the human relationship with God and everything that has been determined in the era of azali including rizki (provision), life partner, and death. It is an absolute provision that can not be denied.

b) Data Analysis Two

In the second data analysis, there is a macrostructure where the theme is displayed; "ajakan demostrasi jihad terhadap musuh-musuh Islam" (The call for a demonstration of jihad against the enemies of Islam)

Referring to the above data presented, the data found in the text is the background displayed in the theme. This can be seen from the situation and condition of the people who cannot be controlled by doing disobedience, munkar (ignorance/denial), mischief and injustice that occurred in the community. Thus, it is contrary to religion. However, the renzim or the government that carries out the duty of the state do not care about the problem. All of these things in the background show the theme. The researcher will describe the word 'demonstrasi' (demonstration) which has a meaning that expressing an opinion in public with the aim to remind each other between fellow Muslims and enforcing amar ma'ruf nahi mungkar. There is also another view that the form of the demonstration is a protest to the government that has been allowing disobedience, crime rampant in this country. All these things is a form of an ideology built into a message of sympathy with the state of this nation as a form of effort to prevent such munkar (ignorance/denial), the meaning contained in the text. 
Tabel 10

The element of macro and microstructure

\begin{tabular}{|c|c|c|}
\hline Discourse Structure & Thing observed & Element \\
\hline Macro Structure & $\begin{array}{l}\text { Schematic } \\
\text { "ajakan demostrasi jihad terhadap musuh-musuh Islam”. (the } \\
\text { allurement of Jihad demonstration against the enemies of } \\
\text { Islam) }\end{array}$ & Topic \\
\hline Super Structure & $\begin{array}{l}\text { Scheme } \\
\text { "ajakan demostrasi jihad terhadap musuh-musuh Islam”. } \\
\text { (the allurement of Jihad demonstration against the enemies of } \\
\text { Islam) }\end{array}$ & $\begin{array}{l}\text { Plot } \\
\text { Opening and content }\end{array}$ \\
\hline Micro-Structure & $\begin{array}{l}\text { Syntax } \\
\text { Musuh musuh Islam } \\
\text { Stylistic } \\
\text { Demontrasi (Demonstration), jihad }\end{array}$ & $\begin{array}{l}\text { Pronoun } \\
\text { Lexicon }\end{array}$ \\
\hline
\end{tabular}

Based on the data above, the researcher can describe that the first part is the macrostructure part which is the schematic or the topic of the text. The theme can be seen in the table above, it becomes a tensile force in the text where the impression is conveyed that in taking steps to minimize disobedience, crime and social disorder by way of preaching. All these steps are labeled as radical attitudes this is a form of government ideology in interpreting the good intentions of related parties. It is seen in terms of the form of the word "jihad melawan musuh Islam" (jihad against the enemies of Islam) which has the meaning is to prevent amar ma'ruf nahi mungkar both with oral and hand instead of by taking up arms or fight is called jihad.

The word "melawan" (against) is a form of active sentence that has the meaning of taking action both physical and non-physical form or speech, while the words "melawan" (the enemies of Islam) which is a pronoun addressed to people who do immoral, crime, mischief, and injustice both Muslims or non-Muslims. Again, the researcher affirms that the words of the enemies of Islam here are not aimed specifically at the unbelievers or seeing from their religion but in general, both Muslims become important benchmarks they conduct disobedience, crime, injustice well done by the government, board members etc. This is the form of ideology that is constructed so that it is displayed as a theme in the text. The data found in the text is the flow of contents as in the quotation below. "Menghadapi kenyataan ini, tokoh-tokoh umat, para ulama, para kiyai dan lain-lain, bergabung dan bersatu untuk mengadakan unjuk rasa (demonstrasi), menuntut agar kemaksiatan, kejahatan dan ketidak adilan ini dibatalkan dan dihentikan". (Facing this fact, prominent people, scholars, religious people and others, joined and united to hold a demonstration, demanding that disobedience, crime, and injustice are canceled and stopped ".

Table 11

The element of the stylistic micro structure

\begin{tabular}{clcc}
\hline Discourse Structure & Things observed & Element \\
\hline Micro-Structure & \multicolumn{2}{c}{ Stylistic } \\
& $\begin{array}{l}\text { Tokoh umat } \\
\text { (religious people) }\end{array}$ & Lexicon \\
\hline
\end{tabular}

Here para ulama, para kiyai were raised as the choice of language here means that the ulama and kiyai have a role in preventing the amar ma'ru nahi mungkar, which is more effective by giving religious enlightenment. Researcher viewed that all of these things are reasonably displayed as themes with the flow. Indeed, we admit that the munkar (ignorance or denial) of our country is extremely increased so that in the text it is asked to unite together and to play a role in preventing such munkar (ignorance or denial, it is emphasized to ulama and kiyai who have a role in undergoing Islamic syiar to be continued to spread, to strengthen ukhuwah Islamiah, and the people maslahat are being kept.

Kholid, -. (2018). The abstract of critical discourse analysis of radicalism labeling by BNPT to Islamic site. International Journal of Linguistics, Literature and Culture, 4(4), 112-126. https://doi.org/10.21744/ijllc.v4n4.277 


\section{Conclusion}

Based on the results and discussion above, the results of this research on the labeling of radicalism using CDA theory are presented by focusing on the main subjects as follows: 1) the radical language criteria 2) the ideology of radicalism in the radical text of the site. 3) BNPT views on site text indicated to spread radicalism. The findings of the data in this study were gathered by focusing on the use of the main theory of CDA proposed by van Dijk and the theory of ideology as a supporting theory. All these things can be described that the criteria of radical language a thing that contains jihad invitation, spreading hatred, Ethnicity, Religion, and Race (SARA) elements. This becomes the attention of BNPT. It all forms the basis for saying that the Islamic site indicated to spread radicalism. There are certain characteristics, but linkage with each ideology. BNPT also has the ideology that the content is very influential on social reaction while the ideology of the site as its own is a very good purpose to deliver the message of aml ma'ruf Nahi mungkar. Then by clarifying the problem related to radical language criterion, researchers only review social semiotics by using Halliday version by looking at the field of discourse. The field of discourse here is the problem of labeling the discourse of radicalism perpetrated by the BNPT on Islamic sites that indicated radical. While the discourse is the authorized officials of the BNPT and the owner of the site indicated social action spread radicalism. Based on the discourse part, the researcher only studied looking at the use of language with reference to CDA theory proposed by van Dijk. It's just looking at aspects of the text itself by analyzing the discrete structure aspects of both macrostructure and microstructure. The two discourse structures are found in the dominant use of language with linguistic features in discourse analysis, in particular, the use of good elements in the textual process of a site considered radical by the language user (text creator), i.e., the most active and passive verb use. The dominance of choice of words from religious language or from Arabic text in Islamic sites such as amar mah'ruf nahimungkar, jihad, ikhwan, martyr, musryrik, fie sabilillah, mujahidin. As for different things, it uses various active verbs. This can be seen as an example of membunuh (killing), berjihad, menyampikan (delivering), mengajak (inviting), berbuat (doing), menasehati (advising), membantu (helping), membuat (making), berdakwah, menyumbat (stopping), jadikan (making), mengerjakan (doing), mencorak (cheering), membersihkan (cleansing), akan mengajar (will be taching), berikhtiar (endeavoring), menjalani (living), mengikuti (following), mengamalkan (practicing), menuntut (demanding), memberi (demanding), menyuci (washing), merapatkan (making closer), and membeli (buying).

\section{Conflict of interest statement and funding sources}

The author declares that I have no competing interest. This study is reported in this publication was supported by STKIP Weetabula, West North Sumba, Indonesia and it has been reviewed and approved by IJSSH in accordance with its policy on objectivity in research.

\section{Statement of authorship}

The author hereby declares that I am the original author of this research. Besides, I have not used any sources other than those listed in the bibliography and identified as references. I further declare that I have not submitted this study at any other institution. In addition, the author has approved the final article.

\section{Acknowledgments}

We would like to extend our gratitude to all those who have given assistance so that this article on the critical review of the literature can be delegated. We also express our gratitude to the input and assistance of Departement of Teacher Training and Education of STKIP Weetabula which has provided a forum for scientific advancement for the advancement of science, especially at the STKIP Weetabula. 
References

Aryani, N. L. (2018). Implementation of Communication Ethics in Building Social Harmony. International Journal of Social Sciences and Humanities (IJSSH), 2(1), 147-156.

Badara, A., \& Hum, M. (2014). Analisis Wacana: Teori, Metode, dan Penerapannya pada Wacana Media. Prenada Media.

Chomsky, N., \& Basyaib, H. (1991). Menguak tabir terorisme internasional. Penerbit Mizan.

Darma, Y. A. (2009). Analisis wacana kritis. Yrama Widya bekerja sama dengan Jurusan Pendididikan Bahasa dan Sastra Indonesia (FPBS UPI).

Eriyanto. (2001). Analisis wacana: pengantar analisis teks media. LKiS Yogyakarta.

Fiske, J. (2010). Introduction to communication studies. Routledge.

Halliday, M. A. K., \& Hasan, R. (1994). Bahasa, Konteks dan Teks; Aspek-aspek Bahasa dalam Pandangan Semiotika Sosial. terj.

Halliday, M. A. K., Matthiessen, C., \& Halliday, M. (2014). An introduction to functional grammar. Routledge.

Halliday, M. A., \& Hasan, R. (1989). Language, context, and text: Aspects of language in a social-semiotic perspective.

Jorgensen, M. W., \& Phillips, L. J. (2010). Discourse Analysis: Theory and Methode (Diterjemahkan oleh Imam Suyitno dkk dengan judul Analisis Wacana: Teori dan Metode). Yogyakarta: Pustaka Pelajar.

Qodir, Z. (2014). Radikalisme Agama Di Indonesia: Pertautan Ideologi PolitikKontemporer dan Kekuasaan.

Setiawan, I. (2015). Systemic Functional Linguistics Analysis of Gender Violence in Lombok Post-Print Media and It's Relevance on Discourse Learning in Higher Education. International Journal of Research in Social Sciences, 5(5), 518-531.

Setiawan, I. (2016). Transitivitas pada kasus kekerasan seksual dalam harianlombok post: sebuah potret ketersudutan perempuandi nusa tenggara barat. Tutur: Cakrawala Kajian Bahasa-Bahasa Nusantara, 2(1), 59-71.

Sobur, A. (2001). Analisis teks media: suatu pengantar untuk analisis wacana, analisis semiotik dan analisis framing. Remaja Rosdakarya.

Suarta, I. M. (2017). Revitalization of Oral Literature Tradition of Balinese Society Based Character Values As Deradicalism Effort. International Journal of Social Sciences and Humanities (IJSSH), 1(3), 8-16.

Tolson, A. (1996). Mediations: texts and discourse in media studies. Hodder Arnold.

Van Dijk, T. A. (2001). Discourse, ideology and context. Folia linguistica, 35(1-2), 11-40.

Kholid, -. (2018). The abstract of critical discourse analysis of radicalism labeling by BNPT to Islamic site. International Journal of Linguistics, Literature and Culture, 4(4), 112-126. https://doi.org/10.21744/ijllc.v4n4.277 


\section{Biography of Author}

\begin{tabular}{|l|l|}
\hline Kholid was born in Sidemen Lauq on December 31 $1^{\text {st }}$ 1986. He completed her study \\
from elementary school to his high school in his hometown. After graduating from \\
high school, he continued his undergraduate study majoring in Indonesian Language \\
Education and Literature in the Muhammadiyah University of Mataram. He graduated \\
in 2013. A year later, she continued her master degree majoring in Indonesian \\
Language Education at Mataram University. Now, he is a lecturer at the undergraduate \\
program of Language Education, Indonesian, and Regional Literature at STKIP \\
Weetabula, West North Sumba (NTT).
\end{tabular}

